\title{
Perancangan Sistem Informasi Pelayanan Rekam Medis di Puskesmas Arcamanik Kota Bandung
}

\author{
Sali Setiatin', Sinta Rizki Agustin ${ }^{2}$ \\ 1,2 Prodi Rekam Medis dan Informasi Kesehatan, Politeknik Piksi Ganesha Bandung \\ ${ }^{1}$ salisetiatin@gmail.com, ${ }^{2}$ sintarizki007@gmail.com
}

\begin{abstract}
This research was aimed to design and build a medical record service information system using PHP and MySQL at UPT Puskesmas Arcamanik Bandung City.Data collection method which used in this research were direct observation to the research location, interviews and literature review. Design method which used were waterfall method with UML (Unified Modelling Language) as a tools, MySQL as database system, and blackbox method as testing system. Problems found in this research were : (1) all of medical record service still manual start from registration, service till the reporting were still manually and its takes a long time, (2) a medical record which lost or slipped were makes a data duplication because the staff create a new medical record. To solve this problem the author suggest to : (1) design an integrated medical record service information system, (2) arrange a training for staff or user, (3) design a web-based information system.
\end{abstract}

Keyword : Information System, Medical Record Service, Web

\begin{abstract}
Abstrak
Penelitian ini bertujuan untuk merancang dan membangun sistem informasi pelayanan rekam medis dengan menggunakan PHP dan MySQL di UPT Puskesmas Arcamanik Kota Bandung. Metode Pengumpulan data yang digunakan dalam penelitian ini adalah dengan melakukan observasi langsung ke tempat penelitian, wawancara serta kajian pustaka. Metode perancangan yang digunakan adalah metode waterfall dengan alat bantu perancangan sistem berupa UML (Unified Modelling Language), database menggunakan MySQL dan pengujian software menggunakan metode blackbox. Permasalahan yang ditemukan pada penelitian : (1) seluruh pelayanan rekam medis masih dilakukan secara manual mulai dari pendaftaran, pelayanan, hingga kegiatan pelaporan masih dilakukan secara manual sehingga menghabiskan waktu yang lama, (2) rekam medis yang hilang atau terselip menimbulkan duplikasi data karena petugas membuatkan rekam medis yang baru. Untuk mengatasi masalah tersebut penulis memberikan saran, diantaranya : (1) merancang sistem informasi pelayanan rekam medis yang terintegrasi, (2) mengadakan pelatihan kepada petugas atau pengguna sistem, (3) merancang sistem informasi berbasis web.
\end{abstract}

Kata Kunci : Sistem Informasi, Pelayanan Rekam Medis, Web

\section{Pendahuluan}

Perkembangan teknologi informasi pada saat ini sudah membuat dunia yang lebih canggih dan memberikan banyak kemudahan dengan banyaknya peralatan yang dapat membantu pekerjaan manusia dan dengan mudahnya akses untuk mendapatkan informasi, baik informasi mengenai hal yang berada di sekitar kita maupun informasi yang bahkan berasal dari dunia internasional.

Berbagai teknologi pun terus dikembangkan dengan banyaknya sistem informasi yang diciptakan membuat pengolahan data menjadi lebih mudah dan tentunya akan mempermudah pekerjaan manusia.
Dengan perkembangan teknologi yang terus meningkat, maka semakin tinggi kebutuhan akan teknologi yang sedang berjalan. Hal itu mendorong berbagai instansi menggunakan teknologi baik di bidang pelayanan maupun di bidang pengolahan data.

Sistem informasi yang bertugas menjadi pengolah data sangatlah diperlukan untuk mendapatkan informasi yang sesuai dengan pekerjaan yang lebih mudah dan proses pengolahan yang lebih cepat. Kecerdasan buatan yang dibuat dalam sebuah sistem bisa terus berjalan dengan hasil yang akurat dan tidak akan berubah selama sistemnya tidak diubah. Saat ini sistem informasi banyak digunakan di berbagai bidang, salah satunya adalah di bidang 
kesehatan. Sistem informasi akan mengelola data kesehatan seperti data rekam medis pasien, data petugas medis, data dasar fasilitas kesehatan dan sebagainya, kemudian mengolahnya menjadi sebuah informasi yang mudah dipahami dalam bentuk laporan (Jogiyanto, 2005).

Pusat Kesehatan Masyarakat (Puskesmas) adalah fasilitas pelayanan kesehatan tingkat pertama yang diselenggarakan pemerintah untuk menciptakan derajat kesehatan masyarakat yang setinggitingginya di wilayah kerjanya. Peran puskesmas sebagai fasilitas kesehatan tingkat pertama tentunya sangat penting dalam membangun derajat kesehatan masyarakat baik dengan upaya promotif, preventif maupun kuratif. Dalam usaha kuratif, puskesmas tentunya harus memberikan pelayanan yang tepat dan cepat kepada pasien, sehingga diperlukan dukungan dari pelayanan penunjang medis lainnya. Salah satunya adalah pelayanan rekam medis.

Berdasarkan Peraturan Menteri Kesehatan Republik Indonesia Nomor 75 Tahun 2014 tentang Pusat Kesehatan Masyarakat menjelaskan bahwa Pusat Kesehatan Masyarakat yang selanjutnya disebut Puskesmas adalah fasilitas pelayanan kesehatan yang menyelenggarakan upaya kesehatan masyarakat dan upaya kesehatan perseorangan tingkat pertama, dengan lebih mengutamakan upaya promotif dan preventif, untuk mencapai derajat kesehatan masyarakat yang setinggi-tingginya di wilayah kerjanya. Sistem Informasi Puskesmas adalah suatu tatanan yang menyediakan informasi untuk membantu proses pengambilan keputusan dalam melaksanakan manajemen Puskesmas untuk mencapai tertib administrasi melalui kegiatan rekam medis yang terdiri dari identifikasi pasien, pengolahan data, pelaporan dan penyimpanan berkas rekam medis (filing). Guna mencapai tujuan tersebut, Departemen Kesehatan menetapkan Peraturan Menteri Kesehatan No. 269/Menkes/PER/III/2008 Tentang Rekam Medis.

Puskesmas harus membina dan mengolah rekam medisnya dengan baik sesuai dengan peraturan yang ada, sebagaimana yang telah diungkapkan oleh Edna K. Huffman : "Rekam Medis yang baik akan mencerminkan pelayanan kesehatan yang baik pula". Rekam medis yang baik adalah rekam medis yang mengandung informasi yang akurat dan dapat dipertanggung jawabkan, dijaga kerapihan serta kebersihannya dan hanya terbatas pada hubungan antara dokter, atau dokter gigi, atau tenaga kesehatan lainnya dan pasien-pasien yang memuat keterangan menggenai riwayat dan perkembangan penyakit, pengobatan serta tindakan yang diberikan tenaga kesehatan kepada pasiennya dan memuat kepastian biaya yang harus dikeluarkan oleh pasien atas pengobatan dirinya.

Pelaksanaan kegiatan unit rekam medis dimulai dari identifikasi pasien, pengolahan data, pelaporan hingga penyimpanan berkas rekam medis (filing). Dalam pengolahan data, terdapat berbagai kegiatan yaitu penataan berkas rekam medis (assembling), pemberian kode (coding) dan tabulasi (indeksing). Kegiatan tersebut saling berkaitan karena berhubungan dengan pengumpulan data untuk penyajian laporan, baik laporan intern maupun ekstern(Depkes RI, 2010).

Rekam medis merupakan dasar dijadikan laporan mengenai kegiatan yang terjadi di Puskesmas, untuk mengetahui gambaran informasi dan merupakan bahan untuk proses perencanaan Puskesmas. Untuk menunjang semua itu perlu adanya laporan yang dibuat oleh rekam medis yang menggambarkan informasi pelayanan yang terjadi di Puskesmas, dengan merekap semua pelayanan dari setiap poliklinik untuk menghasilkan laporan mengenai kondisi kesehatan masyarakat di wilayah kerja Puskesmas, seperti penyakit terbanyak yang menyerang masyarakat di wilayah tersebut, kondisi kesehatan ibu dan anak, banyaknya masyarakat yang menderita penyakit kronis, banyaknya masyarakat yang menderita penyakit menular dan sebagainya (Hatta, 2010).

Untuk mendapatkan suatu laporan kegiatan Puskesmas, maka perlu dilaksanakan pencatatan rekam medis yang menunjang guna menghasilkan laporan yang diperlukan. Pengelolaan rekam medis yang baik akan menghasilkan laporan yang akurat dan dapat membantu dalam pengambilan keputusan.

Berdasarkan hasil pengamatan penulis di UPT Puskesmas Arcamanik Kota Bandung, pelayanan rekam medis masih dilakukan secara manual. Penggunaan komputer hanya untuk membuat register kunjungan harian dan input P-care. Pasien mendaftar dengan mengisi formulir yang disediakan dan mengambil nomor antrian pendaftaran, kemudian di bagian pendaftaran, pencatatan informasi pasien dilakukan secara manual yaitu dengan menulis di buku status pasien (rekam medis). Peningkatan jumlah kunjungan pasien di Puskesmas Arcamanik menuntut petugas untuk melayani pasien lebih 
cepat. Namun seringkali muncul permasalahan yang memperlambat pelayanan sehingga antrian pasien menumpuk.

Untuk kunjungan baru, petugas pendaftaran memberikan nomor rekam medis dengan mencatat data kepala keluarga pasien di buku nomor rekam medis, kemudian membuatkan Kartu Identitas Berobat (KIB) yang diberikan pada pasien dan mencatat data pasien di buku status pasien, untuk kunjungan lama, petugas rekam medis mencarikan status pasien (rekam medis) di loker penyimpanan, terkadang ada beberapa rekam medis yang hilang yang kemungkinan terselip di loker lain atau tersimpan di tempat yang berbeda, hal tersebut membuat pelayanan menjadi lebih lama karena mencari rekam medis yang hilang. Pasien yang tidak membawa kartu berobat pun dapat memperlambat pelayanan karena petugas harus mencari nomor rekam medis pasien di buku nomor rekam medis, sehingga terkadang petugas membuatkan nomor rekam medis baru yang mengakibatkan terjadinya duplikasi data. Setelah itu petugas pendaftaran memasukkan data pasien pada register kunjungan pasien yang dibuat dalam bentuk Ms. Excell, kemudian petugas pendaftaran mendistribusikan rekam medis ke setiap poli sehingga proses pelayanan di poli menjadi terhambat.

Pencatatan pelayanan pasien oleh dokter dan perawat pun dilakukan secara manual. Terkadang masih ada pengisian rekam medis yang tidak lengkap sehingga petugas rekam medis harus mengembalikan rekam medis pada petugas yang bersangkutan untuk dilengkapi. Pengolahan data pasien seperti pemberian kode penyakit, indeksing dan pelaporan masih dilakukan secara manual. Laporan dibuat dalam bentuk Ms. Excell dengan melihat data dari register pelayanan. Belum ada sistem yang terintegrasi yang mampu menghubungkan setiap kegiatan rekam medis dan adanya kemungkinan tak terduga (seperti status pasien tidak ditemukan, pasien tidak membawa kartu berobat, dll) sehingga dapat memperlambat pelayanaN (Depkes RI, 2008).

Maka dengan dukungan teknologi sistem informasi yang akan dirancang penulis akan mempermudah pekerjaan pengelolaan data secara langsung dan dapat digantikan dengan suatu sistem informasi yaitu dengan komputer. Selain cepat, tepat, dan mudah, pengelolaan data juga lebih efektif dengan hasil yang akurat.
Hal tersebut sudah cukup baik, namun belum optimal karena dalam pelayanan rekam medis masih dilakukan secara tulis tangan, pelaporannya pun masih menggunakan pembukuan yang kemudian direkap manual dan di input satu-persatu ke dalam Ms. Excell. Dengan demikian dalam hal tersebut menyebabkan penyampaian informasi menjadi lambat, tidak efektif, dan tidak efisien serta membutuhkan waktu yang cukup lama dalam pelayanan rekam medis.

\section{Metode}

Rancangan penelitian ini adalah evaluasi dan pengembangan dengan menggunakan PHP dan MySQL. Obyek penelitian sistem pelayanan rekam medis di UPT Puskesmas Arcamanik Kota Bandung dan sebagai sunyeknya adalah petugas rekam medis. Teknik pengumpulan data dengan wawancara, studi pustaka. Sedangkan untuk metode pengembangan perangkat lunak dengan metode waterfall. UML (Unified Modelling Language) digunakan sebagai alat bantu penggambaran perancangan, MySQL sebagai Database atau penyimpanan data dan Blackbox sebagai pengujian sistem

\section{Hasil dan Pembahasan}

\section{Perancangan Sistem Informasi}

Pelayanan Rekam Medis yang dirancang ini menggunakan Unified Modelling Language. Perancangan sistem yang digunakan, yaitu Hypertext Preprocessor, dengan database MySQL.

\section{UseCase Diagram Sistem Yang Dirancang}

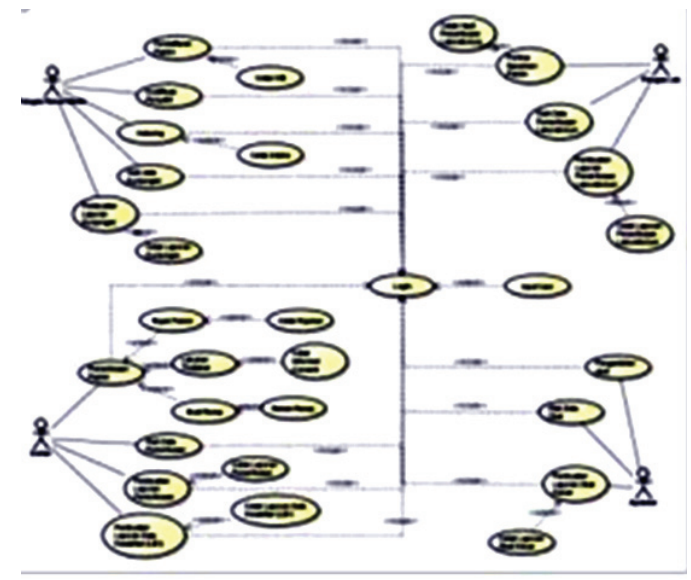

Gambar 1.UseCase Diagram Sistem yang Dirancang 


\section{Class Diagram Sistem Yang Dirancang}

Class Diagram Pendaftaran Pasien Sistem Yang Dirancang

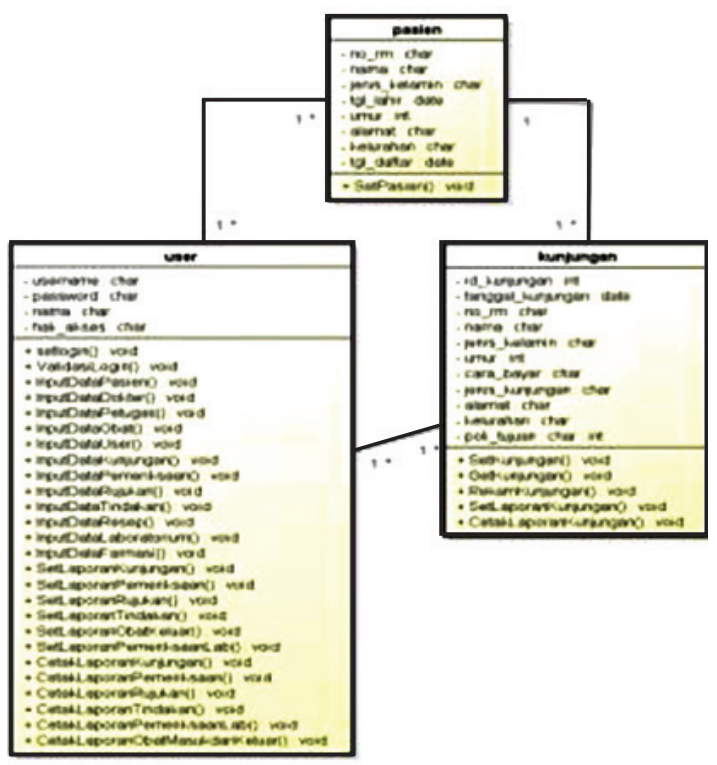

Gambar 2. Class Diagram Pendaftaran Pasien Sistem yang Dirancang

Class Diagram Pemeriksaan Pasien Sistem Yang Dirancang

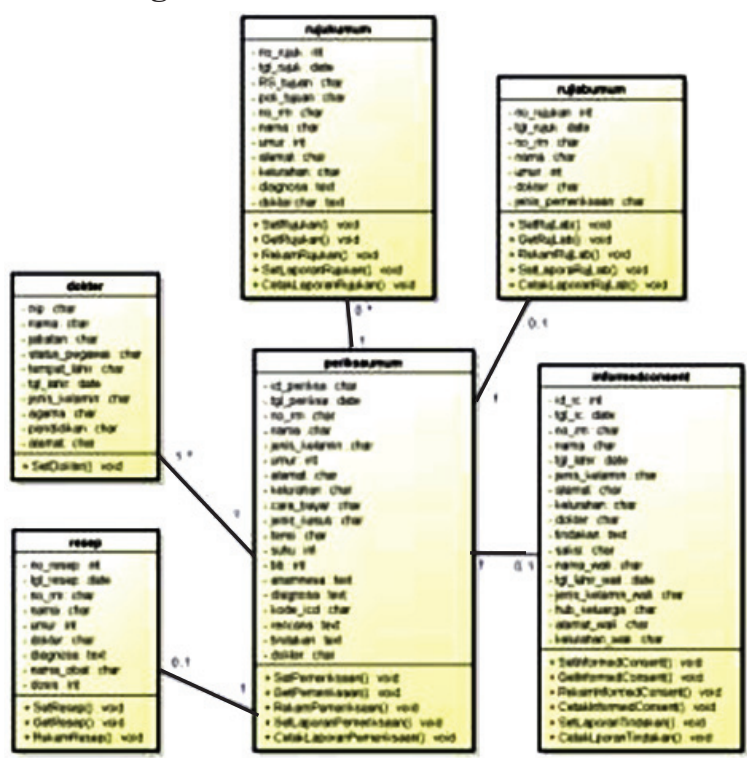

Gambar 3. Class Diagram Pemeriksaan Pasien Sistem yang Dirancang
Class Diagram Laboratorium Sistem Yang Dirancang

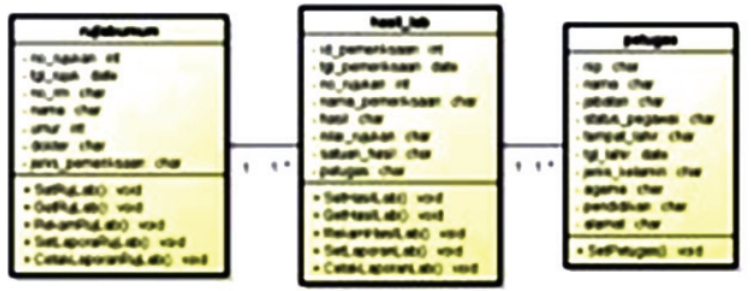

Gambar 4. Class Diagram Laboratorium Sistem yang Dirancang

Class Diagram Farmasi Sistem Yang Dirancang

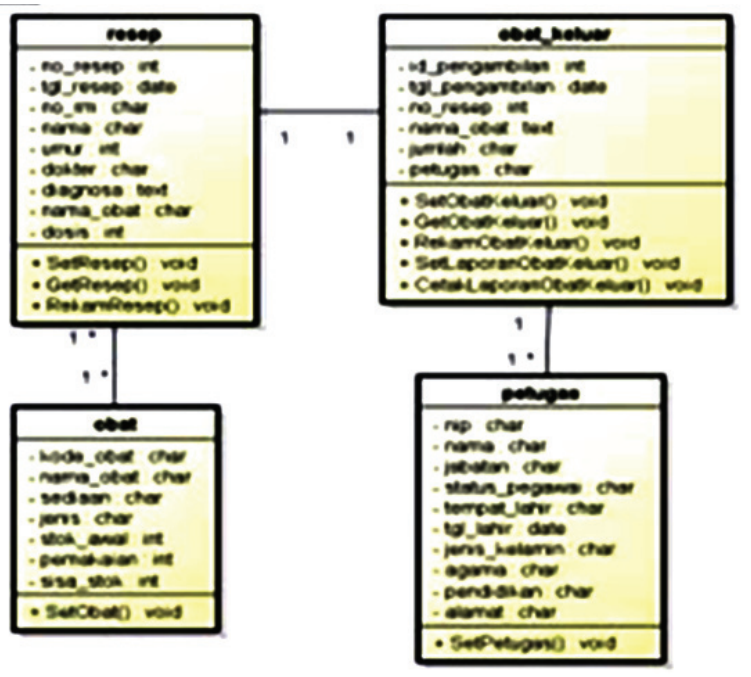

Gambar 5. Class Diagram Farmasi Sistem Yang Dirancang

\section{Activity Diagram Sistem Yang Dirancang}

Activity Diagram Pendaftaran Pasien Sistem Yang Dirancang

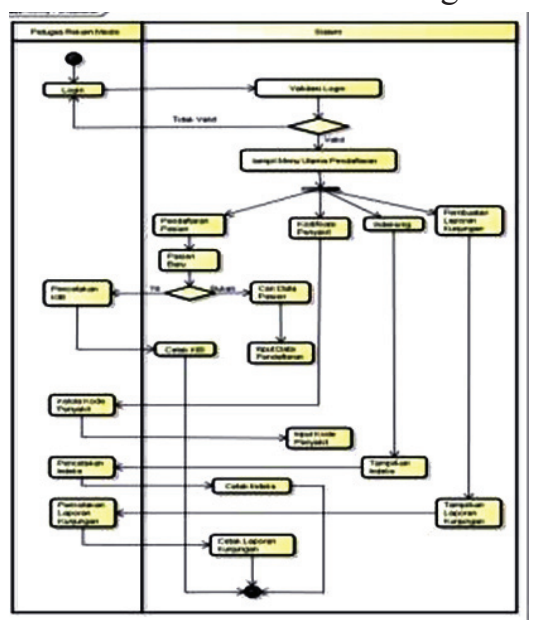

Gambar 6. Activity Diagram Pendaftaran Pasien Sistem Yang Dirancang 
Sali Setiatin, Sinta Rizki Agustin. Perancangan Sistem Informasi Pelayanan Rekam Medis ....

Activity Diagram Pemeriksaan Pasien Sistem Yang Dirancang

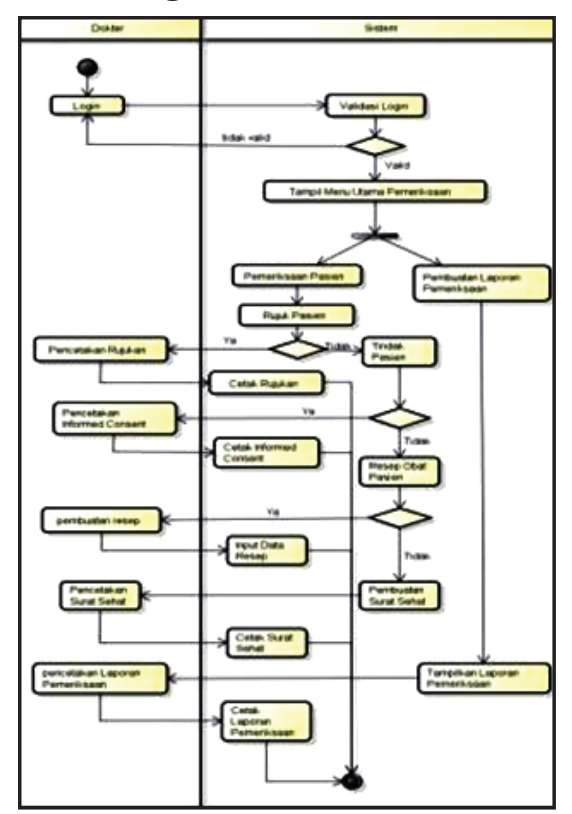

Gambar 7. Activity Diagram Pemeriksaan Pasien Sistem yang Dirancang

Activity Diagram Laboratorium Sistem Yang Dirancang

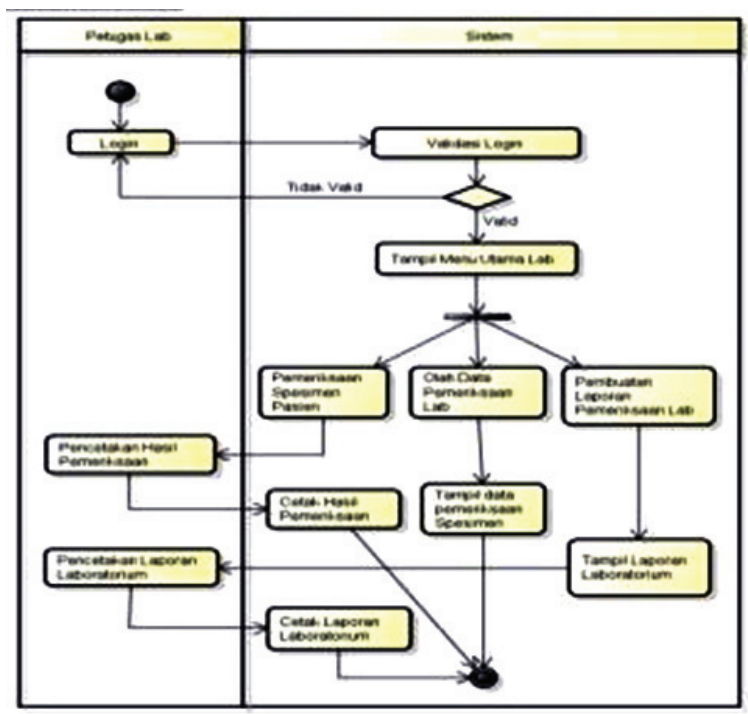

Gambar 8. Activity Diagram Laboratorium Sistem yang Dirancang
Activity Diagram Farmasi Sistem Yang Dirancang

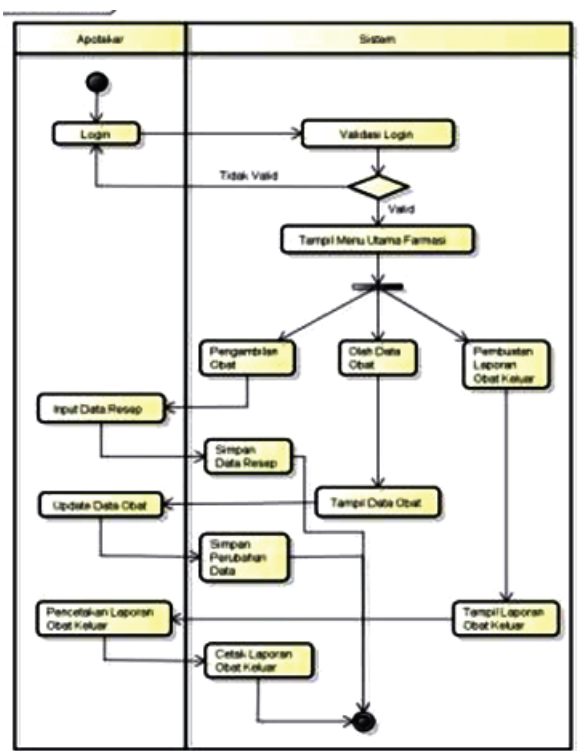

Gambar 9. Activity Diagram Farmasi Sistem yang Dirancang

\section{State Chart Diagram Sistem Yang Dirancang}

State Chart Diagram Pendaftaran Pasien Sistem Yang Dirancang

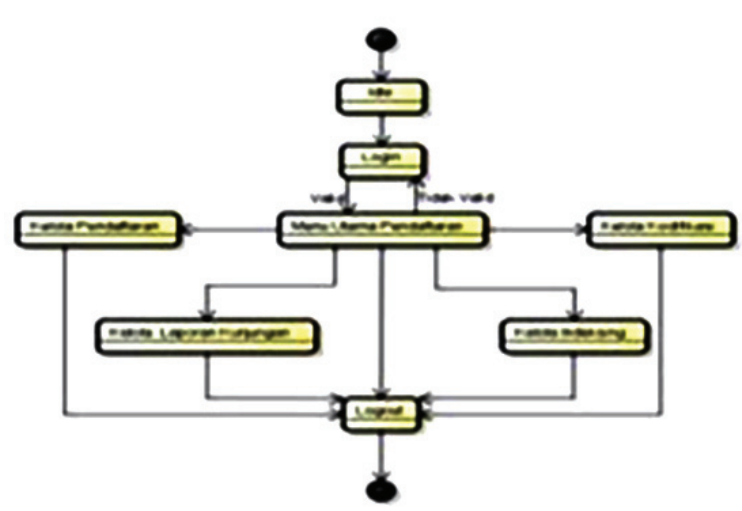

Gambar 10. State Chart Diagram Pendaftaran Pasien Sistem yang Dirancang 
State Chart Diagram Pemeriksaan Pasien Sistem Yang Dirancang

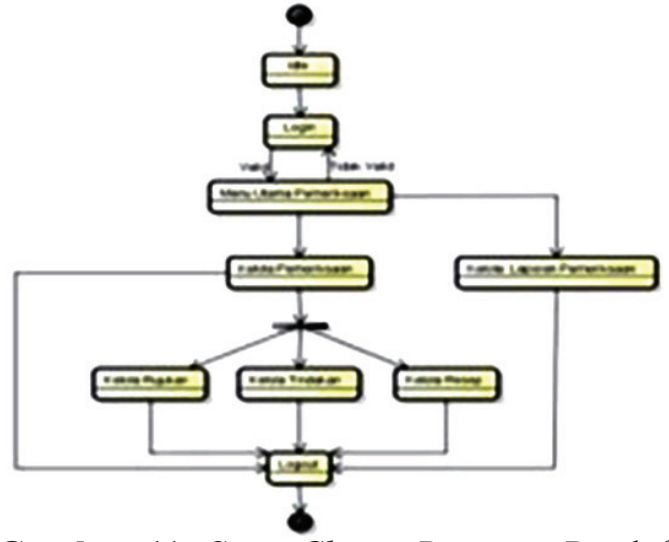

Gambar 11. State Chart Diagram Pendaftaran Pasien Sistem yang Dirancang

State Chart Diagram Laboratorium Sistem Yang Dirancang

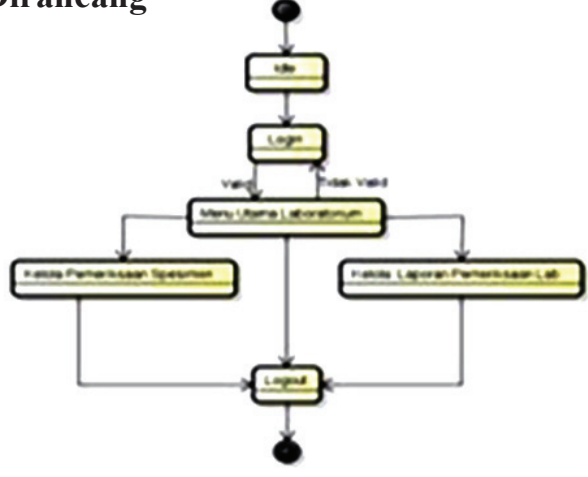

Gambar 12. State Chart Diagram Laboratorium Sistem yang Dirancang

State Chart Diagram Farmasi Sistem Yang Dirancang

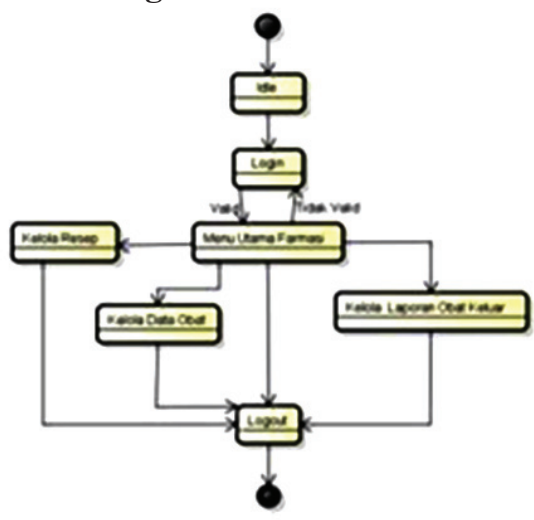

Gambar 13. State Chart Diagram Farmasi Sistem yang Dirancang
Sequence Diagram Sistem Yang Dirancang

Sequence Diagram Pendaftaran Pasien Sistem Yang Dirancang

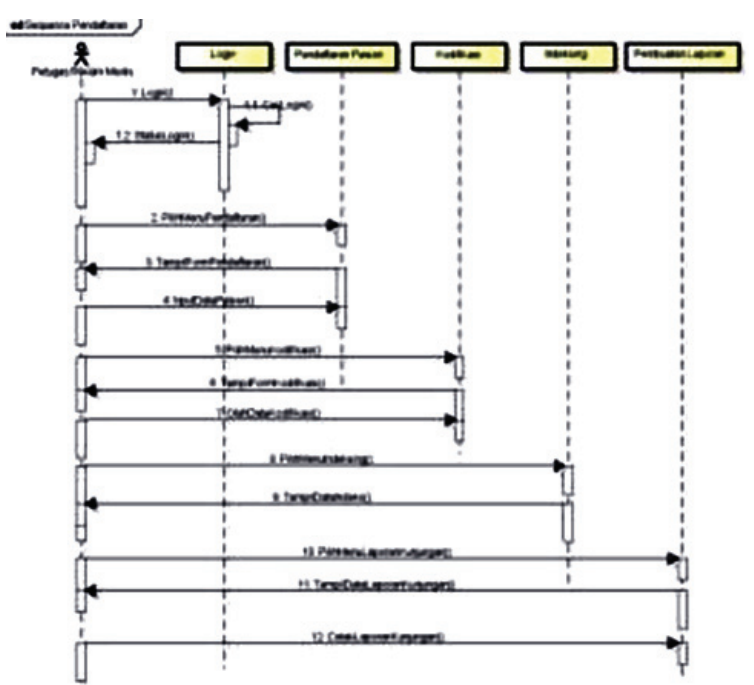

Gambar 13. Sequence Diagram Pendaftaran Pasien Sistem yang Dirancang

Sequence Diagram Pemeriksaan Pasien Sistem Yang Dirancang

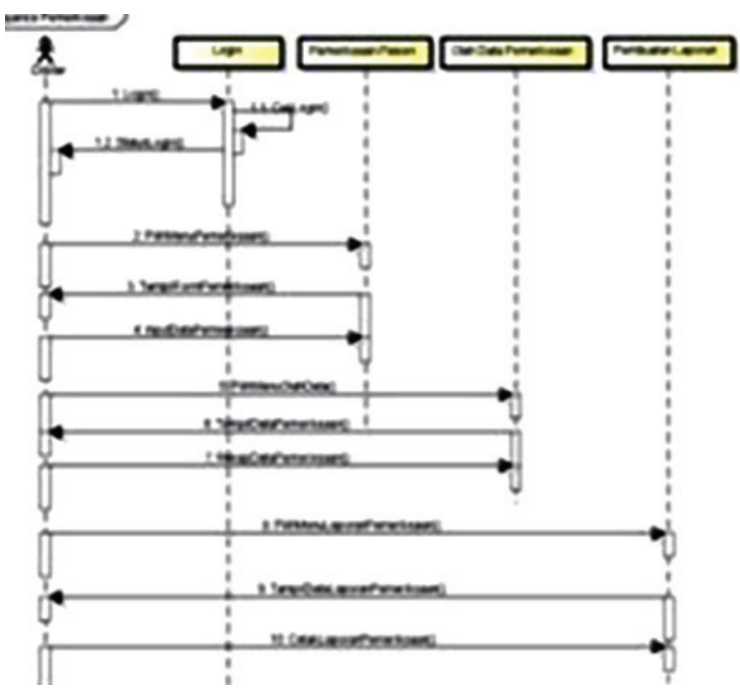

Gambar 14. Sequence Diagram Pemeriksaan Pasien Sistem yang Dirancang 
Sequence Diagram Laboratorium Sistem Yang Dirancang

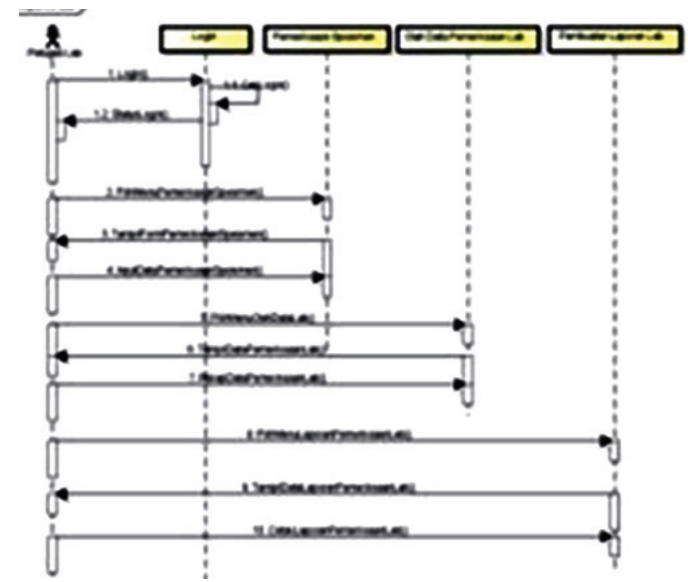

Gambar 15. Sequence Diagram Laboratorium Sistem Yang Dirancang

Sequence Diagram Farmasi Sistem Yang Dirancang

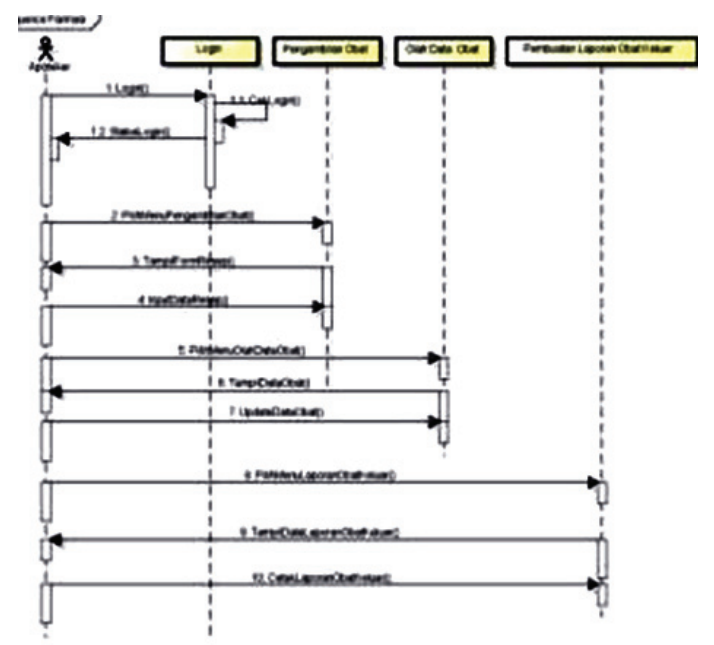

Gambar 16. Sequence Diagram Farmasi Sistem Yang Dirancang

\section{Collaboration Diagram Sistem Yang Dirancang}

Collaboration Diagram Pendaftaran Pasien Sistem Yang Dirancang

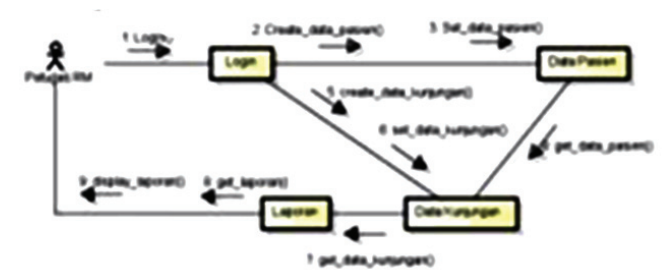

Gambar 17. Collaboration Diagram Pendaftaran Pasien Sistem yang Dirancang
Collaboration Diagram Pemeriksaan Pasien Sistem Yang Dirancang

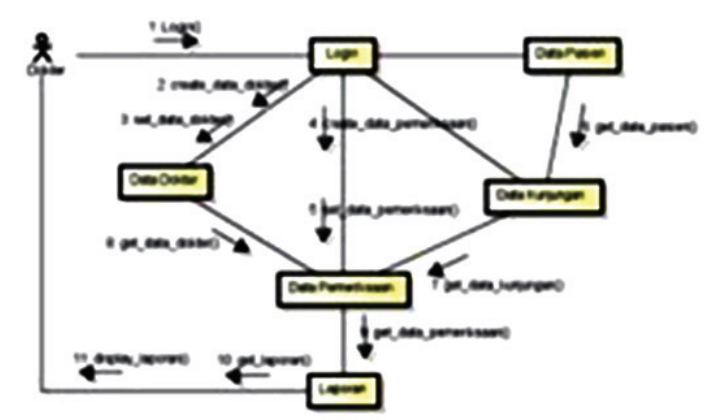

Gambar 18. Collaboration Diagram Pemeriksaan Pasien Sistem Yang Dirancang

Collaboration Diagram Laboratorium Sistem Yang Dirancang

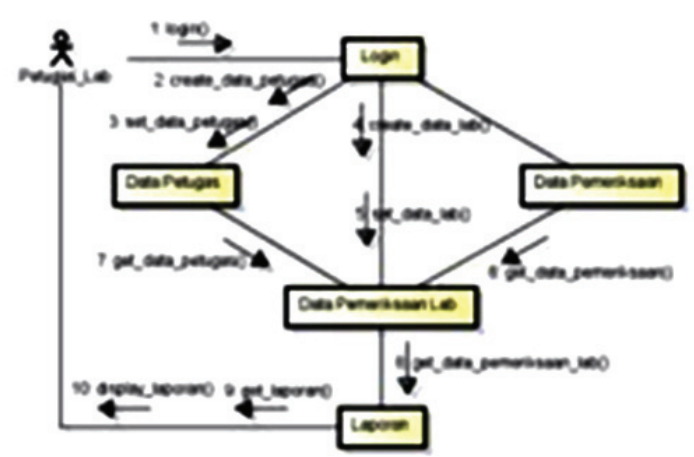

Gambar 19. Collaboration Diagram Laboratorium Sistem yang Dirancang

Collaboration Diagram Farmasi Sistem Yang Dirancang

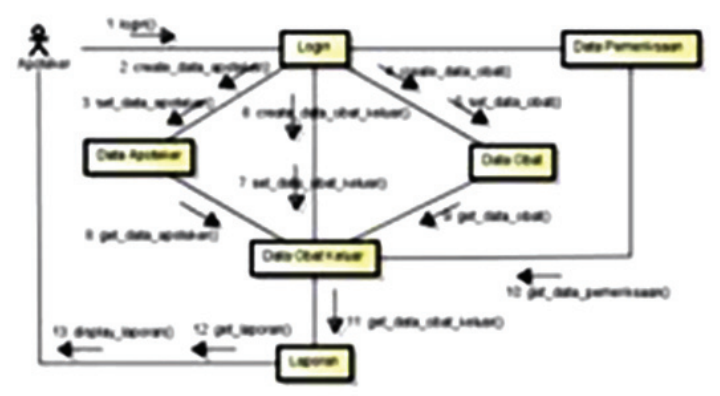

Gambar 20. Collaboration Diagram FarmasiSistem yang Dirancang 


\section{Component Diagram Sistem Yang Dirancang}

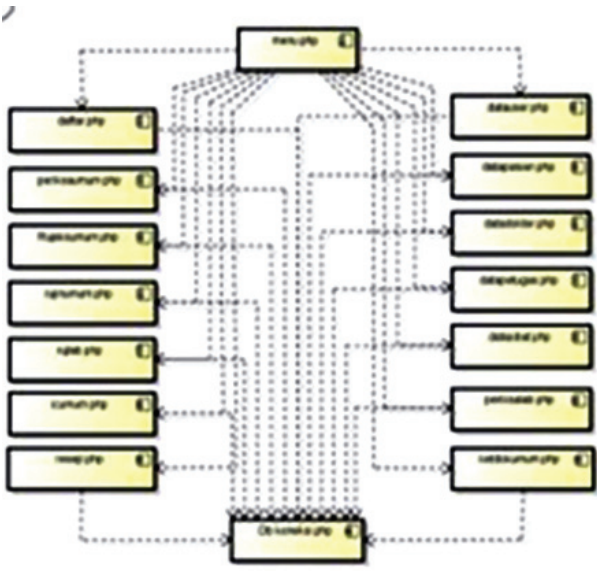

Gambar 21. Component Diagram Sistem yang Dirancang

\section{Deployment Diagram Sistem Yang Dirancang}

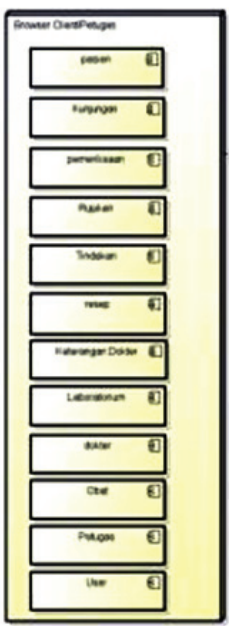

Gambar 22. Deployment Diagram Sistem yang Dirancang

\section{Rancangan Masukan}

Rancangan masukan dalam perancangan sistem informasi ini diawali dengan menampilkan form login user, yaitu langkah awal user untuk mengakses dan melakukan input data rekam medis pasien ke dalam sistem yang nantinya akan diolah dan menghasilkan keluaran laporan.

\section{Rancangan Keluaran}

Rancangan keluaran berisi gambaran tentang keluaran yang dihasilkan oleh sistem yang dirancang. Dalam hal ini penulis merancang sistem informasi Pelayanan rekam medis di UPT Puskesmas Arcamanik Kota Bandung. Keluaran yang dihasilkan oleh rancangan sistem informasi yang penulis buat adalah laporan di media kertas (print out) yang berasal dari olahan database.

\section{Implementasi}

Tahap implementasi sistem merupakan tahap menerjemahkan perancangan berdasarkan hasil analisis dalam bahasa yang dapat dimengerti oleh mesin serta penerapan perangkat lunak pada keadaan yang sesungguhnya.

\section{Form Login}

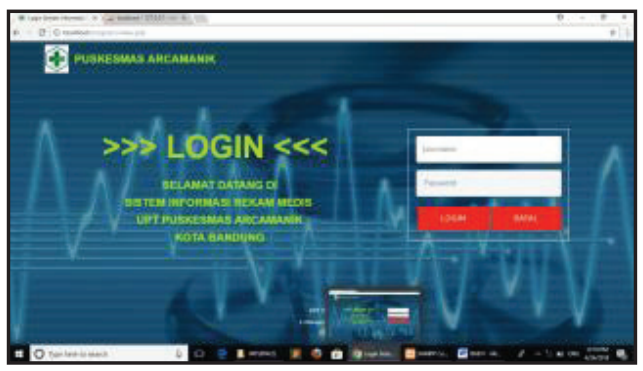

Gambar 23. Form Login

\section{Form Menu Utama}

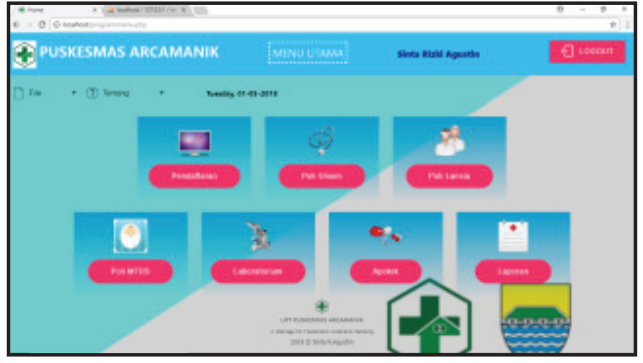

Gambar 24. Form Menu Utama

\section{Form Tambah Data User}

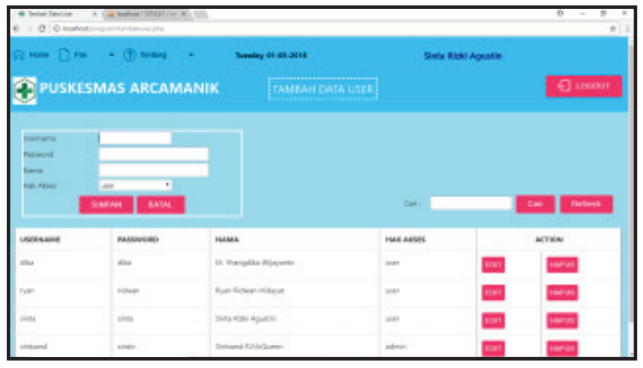

Gambar 25. Form Tambah Data User 
Sali Setiatin, Sinta Rizki Agustin. Perancangan Sistem Informasi Pelayanan Rekam Medis ....

\section{Form Tambah Data Dokter}

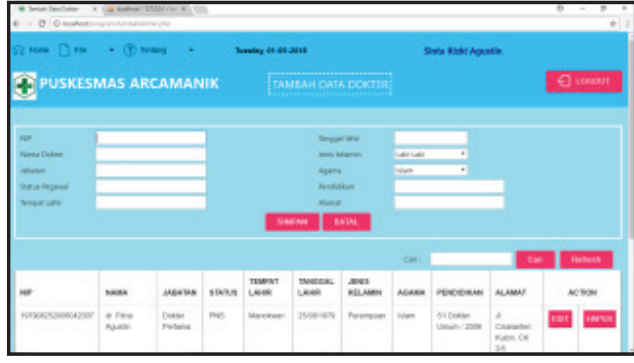

Gambar 26. Form Tambah Data Dokter

\section{Form Tambah Data Pasien}

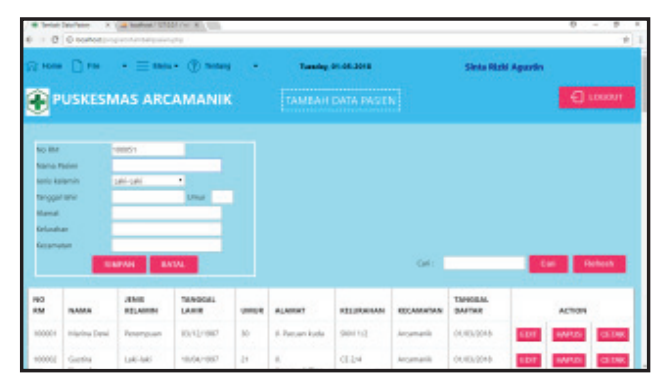

Gambar 27. Form Tambah Data Pasien

6. Form Tambah Data Kunjungan

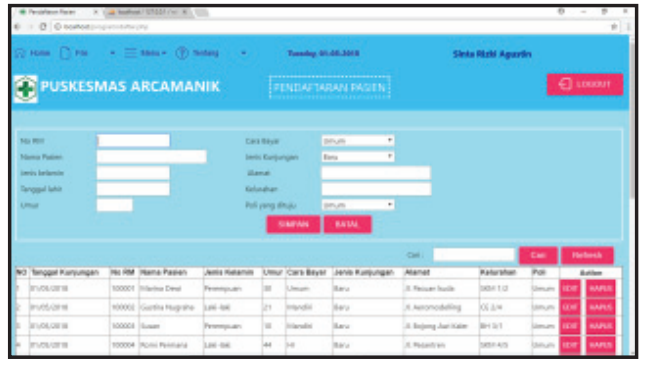

Gambar 28. Form Tambah Data Kunjungan

7. Form Data Pemeriksaan

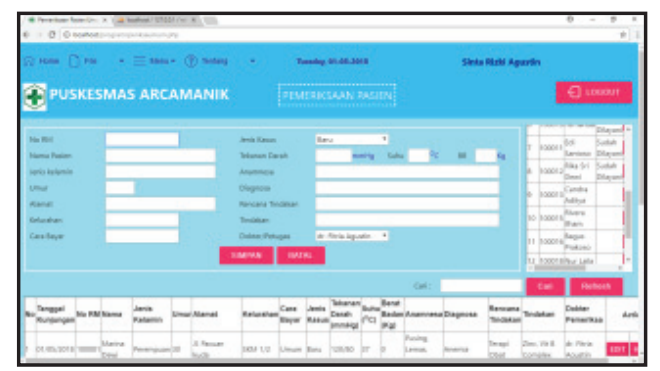

Gambar 29. FormData Pemeriksaan

Sumber : Penulis(Sinta RizkiAgustin, 2018)

\section{Form Data Rujukan}

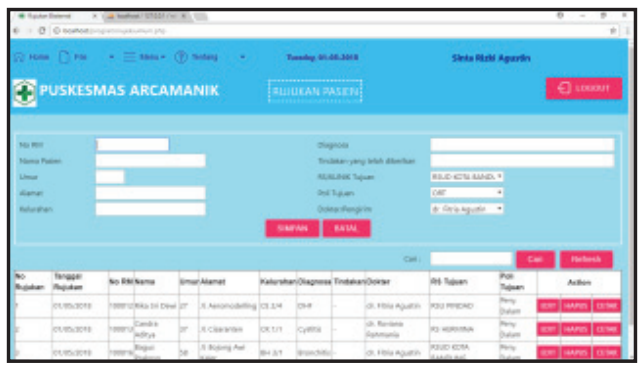

Gambar 30. Form Data Rujukan

9. Form Data Informed Consent

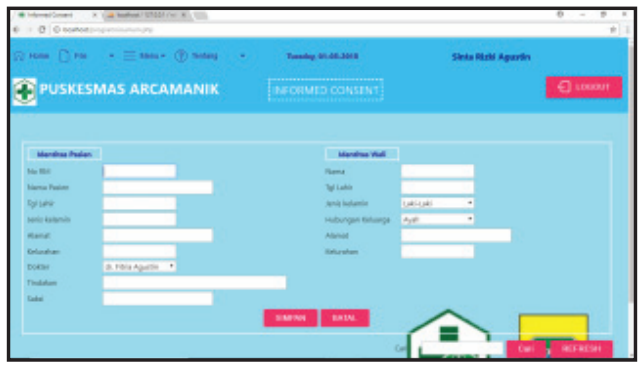

Gambar 31. Form Data InformedConsent

10. Form Data Resep

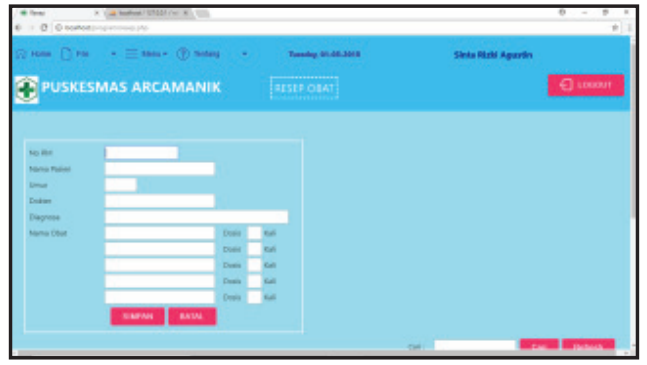

Gambar 32. Form Data Resep

11. Form Data Pemeriksaan Lab

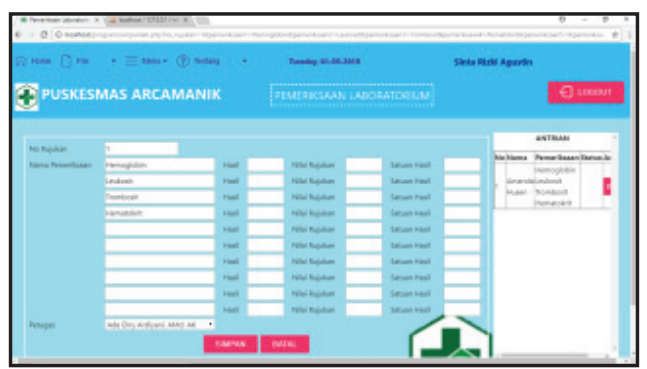

Gambar 33. Form Data Pemeriksaan Lab 


\section{Form Data Pengambilan Obat}

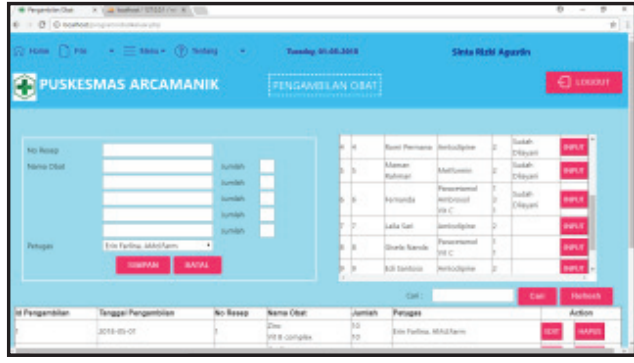

Gambar 34. Form Data Pengambilan Obat

\section{Tampilan Register}

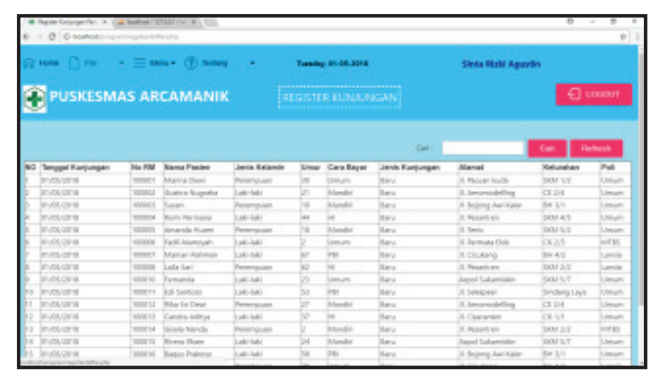

Gambar 35. Tampilan Register

14. Tampilan Laporan

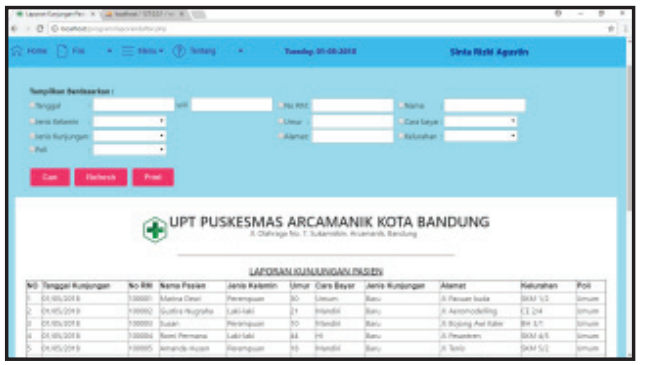

Gambar 36. Tampilan Laporan

\section{Spesifikasi Hardware Dan Software}

Spesifikasi minimal perangkat keras yang digunakan untuk menggunakan Sistem Informasi Pelayanan Rekam Medis adalah sebagai berikut :

1. Processor dengan kecepatan minimal Dual Core $1.60 \mathrm{GHz}$

2. RAM minimal $2 \mathrm{~GB}$

3. Ruang Kosong Harddisk minimal 8 GB

4. VGA minimal $526 \mathrm{MB}$

5. Monitor Resolusi minimal $1024 \times 768$

6. Keyboard dan Mouse standar

7. Printer
Adapun perangkat lunak pendukung yang digunakan untuk membangun sistem informasi pelayanan rekam medis ini adalah sebagai berikut :

1. Sistem Operasi : Windows 7 Ultimate (Minimum)

2. Bahasa Pemrograman : PHP (Hypertext Preprocessor)

3. Pengolahan Database : MySQL

4. Rancangan Diagram : Astah Profesional

5. Rancangan Dialog Layar : Balsamiq Mockups 3

\section{Simpulan}

Perancangan sistem informasi pelayanan rekam medis dengan bahasa pemrograman PHP (Hypertext Preprocessor) dan Database MySQL, sehingga sistem informasi ini mengurangi terjadinya duplikasi data, memiliki penyimpanan data yang lebih aman dan mudah untuk memanipulasi data-datanya, mencari data serta mudah untuk mendapatkan laporan.

Sebagai sarannya adalah perlu diadakan latihan dan sosialisasi bagi petugas yang akan menggunakan sistem informasi pelayanan rekam medis di UPT Puskesmas Arcamanik Kota Bandung.

\section{Daftar Pustaka}

Davis, Gordon B, 2002. Kerangka Dasar Sistem Informasi Manajemen. Bina Alumni Indonesia : Jakarta.

Departemen Kesehatan RI, 2006, Pedoman Penyelenggaraan dan Prosedur Rekam Medis Rumah Sakit. Direktorat Jenderal Bina Pelayanan Medik, Jakarta.

Hatta, Gemala R., 2010.Pedoman Manajemen Informasi Kesehatan disarana pelayanan Kesehatan.Universitas Indonesia : Jakarta.

Jogiyanto, H. M. 2005. Analis dan Desain Sistem Informasi : Pendekatan Terstruktur Teori dan Praktik Aplikasi Bisnis. Andi : Yogyakarta.

Kadir, Abdul, (2003). Pengenalan Sistem Informasi. Andi : Yogyakarta.

Kristanto, Andri, (2008). Perancangan Sistem Informasi. Gava Media : Yogyakarta. 
Sali Setiatin, Sinta Rizki Agustin. Perancangan Sistem Informasi Pelayanan Rekam Medis ....

Peraturan Menteri Kesehatan Republik Indonesia Nomor 269/MENKES/PER 2008, Tentang Rekam Medis.

SK Menkes No 63/Menkes/SK/II/1981, Tentang Sistem Pencatatan dan Pelaporan Terpadu Puskesmas (SP2TP).
Pressman, R. S, (2010). Pendekatan Praktisi Rekayasa Perangkat Lunak. Andi : Yogyakarta.

Susanto, Azhar. (2013). Sistem Informasi

Manajemen. Linggar Jaya: Bandung. 